\title{
Investigating the success of an E-Auction system initiatives among public servants: Validation of an integrated IS success model
}

\author{
Agus Bandiyono $^{1 *}$, Abdul Hamid Hudalil Muttaqin ${ }^{2}$ \\ ${ }^{1}$ Department of Taxation, Polytechnic of State Finance STAN, Tangerang Selatan, Indonesia \\ ${ }^{2}$ Directorate General of State Assets Management, Ministry of Finance of Indonesia, Jakarta, \\ Indonesia \\ *Corresponding Author(s) Email: agusbandiyono@pknstan.ac.id
}

JEL Code:

D23, M41, O30

DOI:

10.31106/jema.v17i2.9044

Article History:

Received 2020/10/29

Reviewed 2020/11/15

Revised 2020/12/13

Accepted 2020/12/30

Licensed:

CC-BY 
Investigating the success of an E-Auction system initiatives among public servants: Validation of an integrated IS success model by Agus Bandiyono, Abdul Hamid Hudalil Muttaqin

\section{Introduction}

The nature of accounting practices has evolved greatly over the years as the rapid change and development of information systems. Information and communication technology (ICT) allows the creation of tools for digitally organizing, transmitting, storing, and acting on information in new ways. With governance and public administration reform in the New Public Management spirit, ICT has driven many innovations in the public sector, particularly e-procurement and e-auction (Svidronova \& Mikus, 2015). Today, the development of information technology has grown quite rapidly. One of its applications is used in the world of commerce, enabling goods to be auctioned or sold online easily and efficiently (Bandiyono $\&$ Indrianto, 2019). The web-based online auction system is a web-based program that was created to make it easier for us to auction or buy and sell goods (Abi Bakri, 2013). The auction implementation in Indonesia is controlled and operated by the Ministry of Finance through the Directorate General of State Assets (DJKN). Implementation of all forms of an auction is carried out through the State Wealth Service Office and Auction (KPKNL) as well as Auction House, which is limited to non-voluntary execution auction and pre-auction implementation (Presidential Regulation No. 28 of 2015). A change of paradigm has emerged from offline auctions to online auctions (P. Lin et al., 2018).

The usage of an online auction system was crucial for not only efficient purposes but also nation strategic goal. Santoso \& Bourpanus (2019) stated that by switching to electronic services, the government can save public money in developing unnecessary infrastructure projects. An online auction service called e-Auction has been introduced by the Directorate General of State Assets (DJKN) in 2014. An e-Auction with Internet Auction Application (ALI) makes auctions easier (accessible anywhere and anytime), more efficient (no need for transportation and accommodation costs), faster (bids are accepted in seconds), and secured (buyer's auction is given paper auction). To participate in the auction, participants are expected to deposit a certain amount of security deposit and are required to pay it off after being selected as the auction winner. E-Auction participants are given the ability to bid on multiple auctions (multiple closed bids) and know each "real-time" bid amount without any intervention from any party, something that may occur in a traditional auction.

After six years of implementation, it is important to evaluate the implementation of eAuctions to ensure that the DJKN e-Auctions have been carried out properly. Although, there is no ultimate measurement of information system (IS) success, there are three theoretical frameworks that mostly used in the area of IS (Rana et al., 2015). The first IS success model 
was introduced by DeLone \& McLean (1992) who initiated to development IS success model by using six factors namely system quality, information quality, user satisfaction, use, individual impact, and organizational impact as dependable measurement. Seddon (1997) introduced the new prescribed model of DeLone \& McLean (1992) by added perceived usefulness as another factor that affects information system adoption. Later in the year 2003, after an extensive review of their original model, Delone \& McLean (2003) proposed the extended IS success model by incorporated 'service quality' and (accounting) net benefits as a substitute for individual and organizational impact construct.

The proposed IS success model of this study is based on DeLone \& McLean (1992), Delone \& McLean (2003), and Seddon (1997) model with some adaptation due to certain rational facts. For example, 'behavioral intention' and 'usage intention' constructs were excluded from the proposed model as this study is focused on actual users of the systems. On the other hand, 'service quality' is added as a new construct in the proposed model. Rana et al. (2015) explains that service quality has a crucial role in enhances the success level of IS implementation as the expanded responsibility of IS departments and the significance of IS in recent decades. Besides, constructs such as perceived ease of use and compatibility were also considered acceptable to be included in the model as they represent the contemplation of users' beliefs about the system's use.

\section{Literature Review}

\section{The Relationship of System Quality, Perceived Usefulness, and Perceived Ease of Use}

System quality can be defined as the degree to which the desired functionalities and performance characteristics of an information system can best address customer needs, with much ease and as minimal problems encountered as possible (Saha, Nath, \& Salehi-Sangari, 2012; Samsurijal, 2019). The relationship between system quality, perceived usefulness, and perceived ease of use has been explored by researchers in various studies. Kim, Lee, \& Law (2008) and Al-Fraihat et al. (2020) stated that one of the significant factors that drivers perceived usefulness was system quality. Handayani et al. (2017), Aldosari et al. (2018), and Verma et al. (2018) added that there is a positive correlation between system quality and perceived ease of use. The more positive user perceptions about system quality, the higher the usefulness and ease of use perception.

$\mathrm{H}_{1}$ : $\quad$ System quality has a positive and significant effect on perceived usefulness

$\mathrm{H}_{2}$ : System quality has a positive and significant effect on perceived ease of use 
Investigating the success of an E-Auction system initiatives among public servants: Validation of an integrated IS success model by Agus Bandiyono, Abdul Hamid Hudalil Muttaqin

The Relationship of Information Quality, Perceived Usefulness, and Perceived Ease of Use

Pinem et al. (2020) defined information quality as users' perception and assessment of overall information quality provided by the system. Zaied, (2012) divided the information quality criteria into six dimensions which are completeness, understandability, security, availability, and accuracy. A study from Almutairi \& Subramanian (2005), Hajiheydari \& Ashkani (2018), and Kang \& Namkung (2019) shows that there is a positive relationship between information quality, perceived usefulness, and perceived ease of use. The more understandable, complete, secure, and accurate information provided by the system, the more positive users perceived the information.

$\mathrm{H}_{3}$ : Information quality has a positive and significant effect on perceived usefulness

$\mathrm{H}_{4}$ : Information quality has a positive and significant effect on perceived ease of use

\section{The Relationship of Service Quality and Perceived Usefulness}

Service quality has a crucial role in enhances the success level of IS implementation as the expanded responsibility of IT departments and the significance of IS in recent decades. While Namin (2017) defined it as the difference in users perception between actual and expectation performances, Lowry \& Wilson (2016) and Sasongko (2018) defined it as the degree of reliability, responsiveness, empathy, assurances, and tangibles to which IS departments provides service to users that meet their expectations. A study from Landrum \& Prybutok (2004) concluded that service quality is an important variable in the success that affects both usefulness and satisfaction with responsiveness and reliability classified as the most important rating. Therefore, it can be concluded that there is a positive relationship between service quality and perceived usefulness.

$\mathrm{H}_{5}$ : $\quad$ Service quality has a positive and significant effect on perceived usefulness

\section{The Relationship of Perceived Ease of Use and Perceived Usefulness}

The positive relationship of perceived ease of use and usefulness is one of the wellknown and established correlational approaches that are commonly used in evaluating the IS success model. Lin et al. (2017) and Sun et al. (2020) described perceived ease of use as the degree to which a person believes about easiness (free of mental and physical effort) to use a particular system. Also, perceived of usefulness is the extent of which individual beliefs that using a particular system will improve/enhance their performance (Mun, Khalid, \& Nadarajah, 2017; Lee et al. 2018; Rauschnabel \& Ro, 2016). The more easy to use and useful a system, the higher users willingness to apply that particular system. 
$\mathrm{H}_{6}$ : Perceived ease of use has a positive and significant effect on perceived usefulness

The Relationship of System Quality, Information Quality, Service Quality, and Compatibility

Handayani et al. (2017) and Alghazi et al. (2020) defined compatibility as the extent to which a system is perceived as being consistent in maintaining existing value, needs, and performing their required functions. In simple meaning, Rahman et al. (2020) described compatibility as the positive interaction (innovation fit) between users and the application. Prior studies from Alzahrani, Al-Karaghouli, \& Weerakkody (2017) and Aldholay et al. (2018) suggest that the greater the overall quality that consist of system quality, information quality, and service quality of newer technologies, the more likely that these will enhances desires and lifestyles of their users.

$\mathrm{H}_{7 \mathrm{a}}$ : System quality has a positive and significant effect on compatibility

$\mathrm{H}_{7 \mathrm{~b}}$ : Information quality has a positive and significant effect on compatibility

$\mathrm{H}_{7 \mathrm{c}}$ : Service quality has a positive and significant effect on compatibility

The Relationship of System Quality, Information Quality, Service Quality, Perceived Usefulness, Perceived Ease of Use, Compatibility and User Satisfaction

User satisfaction is another well-known IS success model constructs that widely used over decades. While Nwankpa \& Roumani (2014) and Montesdioca \& Maçada (2015) referred to user satisfaction as the degree to which users confident and believes that a system meets their needs. Navimipour \& Soltani (2016) defined user satisfaction as the sum of positive and negative user (subjective) experiences to a particular information system. A previous study from Aldholay et al. (2018) established a meaningful relationship between overall quality and user satisfaction with regards to online learning students in Yemeni. Moreover, the specific correlation of each quality dimensional namely system quality, information quality, and service quality on user satisfactions scientifically proved by Song et al. (2017), Lien, Cao, \& Zhou (2017), Aldholay et al. (2018), Chen \& Chang (2018), Sebetci, (2018), and Koh \& Kan (2020). Finally, prior studies of Lin \& Wang (2012), Liaw \& Huang (2013), Aldholay et al. (2018), and Sebetci (2018) that there is a positive relationship between compatibility, perceived usefulness, and ease of use and user satisfaction. Therefore, the proposed hypotheses of this study can be described as follows.

$\mathrm{H}_{8}$ : System quality has a positive and significant effect on user satisfaction

$\mathrm{H}_{9}$ : Information quality has a positive and significant effect on user satisfaction 
Investigating the success of an E-Auction system initiatives among public servants: Validation of an integrated IS success model by Agus Bandiyono, Abdul Hamid Hudalil Muttaqin

$\mathrm{H}_{10}$ : Service quality has a positive and significant effect on user satisfaction

$\mathrm{H}_{11}$ : Perceived usefulness has a positive and significant effect on user satisfaction

$\mathrm{H}_{12}$ : Perceived ease of use has a positive and significant effect on user satisfaction

$\mathrm{H}_{13}$ : Compatibility of use has a positive and significant effect on user satisfaction

\section{Methods}

Figure 1. Research Framework

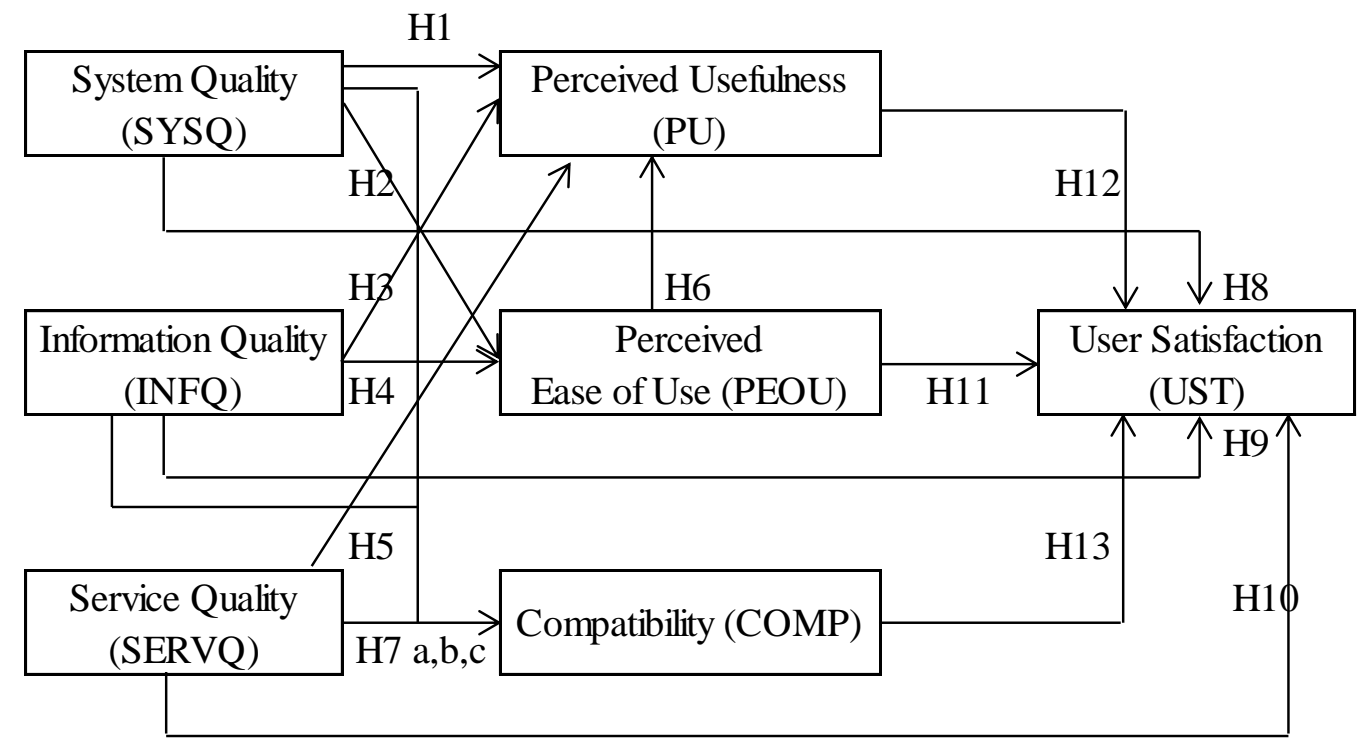

The proposed integrated IS success model used in this study can be seen in Figure 1. To examine the success of the E-Auction system that is developed by the Directorate General of State Assets Management (DJKN), Ministry of Finance of Indonesia, the researchers contemplated survey as an appropriate research method. Büyüköztürk et al. (2010) and Samsurijal (2019) defined survey method as an explanatory survey that aims to explain the relationship between variables and to identify the perceptions or characteristics of targeted population or samples. The structured questionnaire with five-point Likert (where 1 denotes 'Strongly Disagree' and 5 denotes 'Strongly Agree') was used in this study to measure the proposed model. Purposive sampling was chosen as a sampling technique with the auction officials of Directorate of Auction DJKN that have experiences in using E-Auction systems were the selected criterion of a respondent to this study. A total of 700 questionnaires were distributed through each administrator with more than 200 valid samples were used for analysis in this study. Also, the researchers adopted all of the measures from prior literature. Table 1 shows a detailed description of each questionnaire item. 
Table 1. Questionnaire Items

\begin{tabular}{|c|c|c|c|}
\hline Variables & Code & Item & Reference \\
\hline System & SYSQ1 & I would find the E-Auction system to be easy to use. & \multirow{3}{*}{ Rana et al. (2015) } \\
\hline \multirow{2}{*}{$\begin{array}{l}\text { Quality } \\
\text { (SYSQ) }\end{array}$} & SYSQ2 & I would find the E-Auction system to be easy to learn. & \\
\hline & SYSQ3 & E-Auction system would be user friendly. & \\
\hline \multirow{5}{*}{$\begin{array}{l}\text { Information } \\
\text { Quality } \\
\text { (INFQ) }\end{array}$} & INFQ1 & $\begin{array}{l}\text { Information provided by the E-Auction system would } \\
\text { be reliable. }\end{array}$ & \multirow{5}{*}{$\begin{array}{c}\text { Lin et al. (2011), } \\
\text { Lin \& Wang } \\
\text { (2012), Rana et al. } \\
\text { (2015) }\end{array}$} \\
\hline & INFQ2 & $\begin{array}{l}\text { Information provided by the E-Auction system would } \\
\text { be accurate. }\end{array}$ & \\
\hline & INFQ3 & $\begin{array}{l}\text { Information provided by the E-Auction system would } \\
\text { be understandable. }\end{array}$ & \\
\hline & INFQ4 & $\begin{array}{l}\text { E-Auction system would provide sufficient } \\
\text { information. }\end{array}$ & \\
\hline & INFQ5 & $\begin{array}{l}\text { Through the E-Auction system, I would get up-to-date } \\
\text { information. }\end{array}$ & \\
\hline \multirow{5}{*}{$\begin{array}{l}\text { Service } \\
\text { Quality } \\
\text { (SERVQ) }\end{array}$} & SERVQ1 & E-Auction system would provide dependable services. & \multirow{5}{*}{$\begin{array}{l}\text { Lin et al. (2011), } \\
\text { Rana et al. }(2015)\end{array}$} \\
\hline & SERVQ2 & $\begin{array}{l}\text { E-Auction system would provide services at the time } \\
\text { it promises. }\end{array}$ & \\
\hline & SERVQ3 & $\begin{array}{l}\text { E-Auction system would enable interactive } \\
\text { communication. }\end{array}$ & \\
\hline & SERVQ4 & E-Auction system would provide service as promised. & \\
\hline & SERVQ5 & E-Auction system keeping users informed. & \\
\hline \multirow{3}{*}{$\begin{array}{l}\text { Perceived } \\
\text { Usefulness } \\
(\mathrm{PU})\end{array}$} & PU1 & $\begin{array}{l}\text { Using the E-Auction system in my job increases my } \\
\text { productivity. }\end{array}$ & \multirow{3}{*}{$\begin{array}{l}\text { Chau \& } \mathrm{Hu}(2002) \text {, } \\
\text { Hung et al. (2012) }\end{array}$} \\
\hline & PU2 & $\begin{array}{l}\text { Using the E-Auction system enables me to } \\
\text { accomplish tasks more quickly. }\end{array}$ & \\
\hline & PU3 & Overall, I find the E-Auction system useful in my job. & \\
\hline \multirow{3}{*}{$\begin{array}{l}\text { Perceived } \\
\text { Ease of Use } \\
(\text { PEOU) }\end{array}$} & PEOU1 & $\begin{array}{l}\text { I find it easy to get the E-Auction system to do what I } \\
\text { want them to do. }\end{array}$ & \multirow{3}{*}{$\begin{array}{l}\text { Chau \& } \mathrm{Hu}(2002) \text {, } \\
\text { Hung et al. (2012) }\end{array}$} \\
\hline & PEOU2 & $\begin{array}{l}\text { Learning to work with an E-Auction system is easy } \\
\text { for me. }\end{array}$ & \\
\hline & PEOU3 & $\begin{array}{l}\text { It would be easy for me to become skillful at using } \\
\text { the E-Auction system. }\end{array}$ & \\
\hline \multirow{2}{*}{$\begin{array}{l}\text { Compatibility } \\
(\mathrm{COMP})\end{array}$} & COMP1 & E-Auction system is compatible with my need. & \multirow{2}{*}{$\begin{array}{c}\text { Ifinedo (2012), } \\
\text { Zhang, Li, \& Sun } \\
\text { (2014) }\end{array}$} \\
\hline & COMP2 & $\begin{array}{l}\text { E-Auction system is compatible with my job } \\
\text { description. }\end{array}$ & \\
\hline User & UST1 & Overall, I'm satisfied with the E-Auction system. & \multirow{3}{*}{$\begin{array}{l}\text { Sun et al. (2008), } \\
\text { Wang (2008) }\end{array}$} \\
\hline Satisfaction & UST2 & E-Auction system has met my expectations. & \\
\hline$(\mathrm{UST})$ & UST3 & E-Auction system is really enjoya & \\
\hline
\end{tabular}


Investigating the success of an E-Auction system initiatives among public servants: Validation of an integrated IS success model by Agus Bandiyono, Abdul Hamid Hudalil Muttaqin

Table 2. Validity and Reliability Result

\begin{tabular}{|c|c|c|c|c|c|}
\hline Variable/Item & $\begin{array}{c}\text { Pearson } \\
\text { Correlation }\end{array}$ & Criteria & $\begin{array}{c}\text { Cronbach's } \\
\text { Alpha }\end{array}$ & Criteria & Decision \\
\hline SYSQ & & & 0.876 & $>0.600$ & Reliable \\
\hline SYSQ1 & 0.915 & $>0.131$ & & & Valid \\
\hline SYSQ2 & 0.915 & $>0.131$ & & & Valid \\
\hline SYSQ3 & 0.856 & $>0.131$ & & & Valid \\
\hline INFQ & & & 0.866 & $>0.600$ & Reliable \\
\hline INFQ1 & 0.852 & $>0.131$ & & & Valid \\
\hline INFQ2 & 0.730 & $>0.131$ & & & Valid \\
\hline INFQ3 & 0.839 & $>0.131$ & & & Valid \\
\hline INFQ4 & 0.846 & $>0.131$ & & & Valid \\
\hline INFQ5 & 0.842 & $>0.131$ & & & Valid \\
\hline SERVQ & & & 0.871 & $>0.600$ & Reliable \\
\hline SERVQ1 & 0.868 & $>0.131$ & & & Valid \\
\hline SERVQ2 & 0.835 & $>0.131$ & & & Valid \\
\hline SERVQ3 & 0.796 & $>0.131$ & & & Valid \\
\hline SERVQ4 & 0.748 & $>0.131$ & & & Valid \\
\hline SERVQ5 & 0.850 & $>0.131$ & & & Valid \\
\hline PU & & & 0.843 & $>0.600$ & Reliable \\
\hline PU1 & 0.900 & $>0.131$ & & & Valid \\
\hline PU2 & 0.826 & $>0.131$ & & & Valid \\
\hline PU3 & 0.894 & $>0.131$ & & & Valid \\
\hline PEOU & & & 0.739 & $>0.600$ & Reliable \\
\hline PEOU1 & 0.783 & $>0.131$ & & & Valid \\
\hline PEOU2 & 0.791 & $>0.131$ & & & Valid \\
\hline PEOU3 & 0.870 & $>0.131$ & & & Valid \\
\hline COMP & & & 0.752 & $>0.600$ & Reliable \\
\hline COMP1 & 0.899 & $>0.131$ & & & Valid \\
\hline COMP2 & 0.892 & $>0.131$ & & & Valid \\
\hline UST & & & 0.851 & $>0.600$ & Reliable \\
\hline UST1 & 0.866 & $>0.131$ & & & Valid \\
\hline UST2 & 0.870 & $>0.131$ & & & Valid \\
\hline UST3 & 0.898 & $>0.131$ & & & Valid \\
\hline
\end{tabular}


The results of the validity and reliability testing in Table 2 show that all instruments used in this study were valid and reliable as the value of Pearson correlation (r-value) and Cronbach's Alpha was higher than 0.131 and 0.600. Therefore, all instruments in this study can be used to analyze the proposed hypotheses.

\section{Result and Discussion}

Figure 2. Results of Regression Analysis

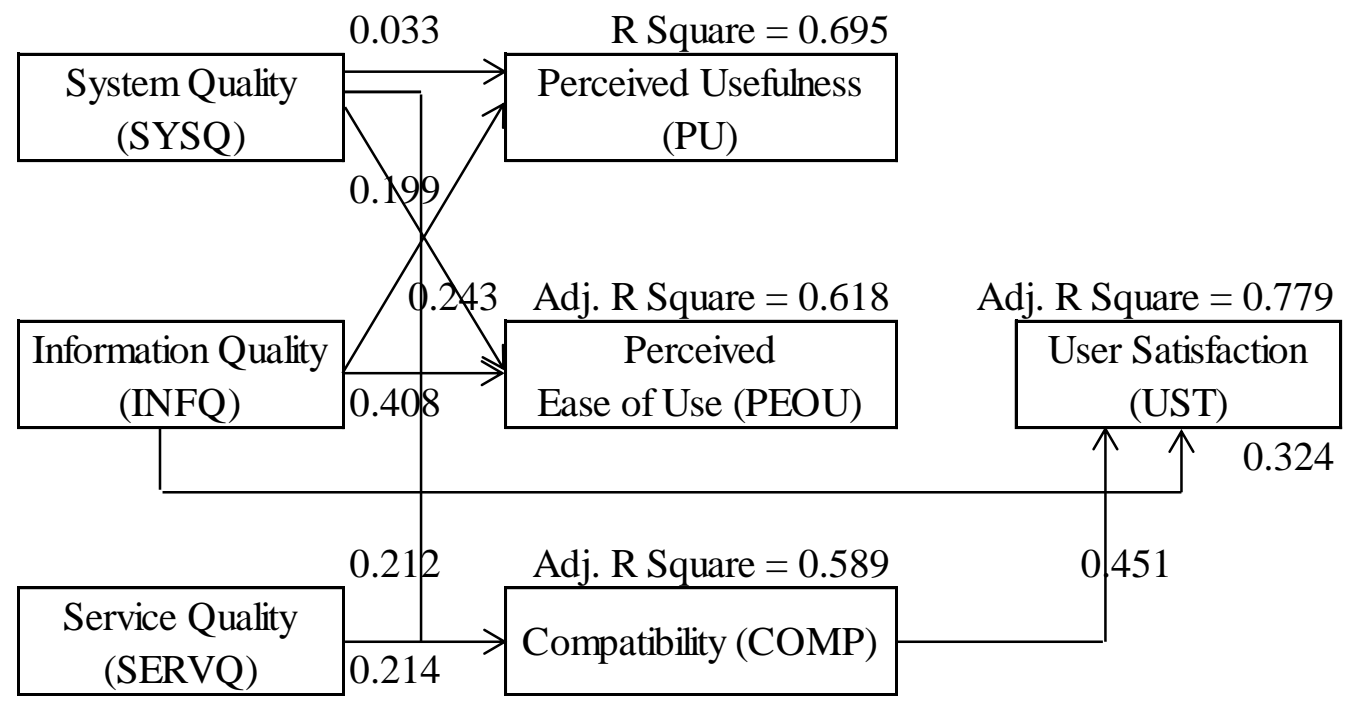

Table 3. Regression Coefficients on Perceived Usefulness

\begin{tabular}{lccccc}
\hline Variables & Coeff. $(\boldsymbol{\beta})$ & t-Value & Sig. & $\begin{array}{c}\text { Sig. } \\
\text { Criteria }\end{array}$ & Decision \\
\hline SYSQ & 0.320 & 2.170 & 0.033 & $<0.050$ & $\mathrm{H}_{1}$ Accepted \\
INFQ & 0.586 & 5.615 & 0.000 & $<0.050$ & $\mathrm{H}_{3}$ Accepted \\
SERVQ & -0.159 & -1.444 & 0.153 & $<0.050$ & $\mathrm{H}_{5}$ Rejected \\
PEOU & -0.077 & -0.606 & 0.546 & $<0.050$ & $\mathrm{H}_{6}$ Rejected \\
\hline
\end{tabular}

Table 4. Average Score Comparison of Overall Quality Items

\begin{tabular}{lccccc}
\hline Items & Average & Items & Average & Items & Average \\
\hline SYSQ1 & 4.084 & INFQ1 & 4.120 & SERVQ1 & 4.120 \\
SYSQ2 & 4.072 & INFQ2 & 3.964 & SERVQ2 & 4.036 \\
SYSQ3 & 3.824 & INFQ3 & 4.096 & SERVQ3 & 3.831 \\
& & INFQ4 & 3.964 & SERVQ4 & 4.120 \\
& & INFQ5 & 4.024 & SERVQ5 & 4.096 \\
\hline
\end{tabular}


Investigating the success of an E-Auction system initiatives among public servants: Validation of an integrated IS success model by Agus Bandiyono, Abdul Hamid Hudalil Muttaqin

Table 5. Regression Coefficients on Perceived Ease of Use

\begin{tabular}{lccccc}
\hline Variables & Coeff. $(\boldsymbol{\beta})$ & t-Value & Sig. & $\begin{array}{c}\text { Sig. } \\
\text { Criteria }\end{array}$ & Decision \\
\hline SYSQ & 0.199 & 3.646 & 0.008 & $<0.050$ & $\mathrm{H}_{2}$ Accepted \\
INFQ & 0.408 & 2.734 & 0.000 & $<0.050$ & $\mathrm{H}_{4}$ Accepted \\
\hline
\end{tabular}

Table 6. Regression Coefficients on Compatibility

\begin{tabular}{lccccc}
\hline Variables & Coeff. $(\boldsymbol{\beta})$ & t-Value & Sig. & $\begin{array}{c}\text { Sig. } \\
\text { Criteria }\end{array}$ & Decision \\
\hline SYSQ & 0.212 & 2.143 & 0.035 & $<0.050$ & $\mathrm{H}_{7 \mathrm{a}}$ Accepted \\
INFQ & 0.009 & 0.129 & 0.898 & $<0.050$ & $\mathrm{H}_{7 \mathrm{~b}}$ Rejected \\
SERVQ & 0.214 & 2.763 & 0.007 & $<0.050$ & $\mathrm{H}_{7 \mathrm{c}}$ Accepted \\
\hline
\end{tabular}

Table 7. Regression Coefficients on User Satisfaction

\begin{tabular}{lccccc}
\hline Variables & Coeff. $(\boldsymbol{\beta})$ & t-Value & Sig. & $\begin{array}{c}\text { Sig. } \\
\text { Criteria }\end{array}$ & Decision \\
\hline SYSQ & 0.153 & 1.238 & 0.220 & $<0.050$ & $\mathrm{H}_{8}$ Rejected \\
INFQ & 0.324 & 3.258 & 0.002 & $<0.050$ & $\mathrm{H}_{9}$ Accepted \\
SERVQ & -0.008 & -0.090 & 0.928 & $<0.050$ & $\mathrm{H}_{10}$ Rejected \\
PU & 0.012 & 0.127 & 0.899 & $<0.050$ & $\mathrm{H}_{11}$ Rejected \\
PEOU & 0.069 & 0.650 & 0.518 & $<0.050$ & $\mathrm{H}_{12}$ Rejected \\
COMP & 0.451 & 3.408 & 0.001 & $<0.050$ & $\mathrm{H}_{13}$ Accepted \\
\hline
\end{tabular}

The IS success model of this study was constructed by combining DeLone \& McLean (1992), Delone \& McLean (2003), and Seddon (1997) model with some adaptation due to the certain rational facts. A total of six independent variables namely system quality, information quality, service quality, perceived usefulness, perceived ease of use, and compatibility were used to measures the success (satisfaction) of E-Auction implementation in Directorate of Auction, DJKN. A regression analysis was performed on system quality, information quality, service quality, and perceived ease of use with perceived usefulness as the dependent variable. The model examined an adjusted $\mathrm{R}^{2}$ of 0.695 (Figure 2). The result of this study did not find sufficient evidence to support the positive relationship between service quality and perceived usefulness. The value of t-tested between variables as shown in Table 3 was -0.159 
and -0.077 with a significant value of 0.153 and 0.546 (which is higher than significances criteria of 0.050), therefore $\mathrm{H}_{5}, \mathrm{H}_{6}$ is rejected. The majority of the respondent in this study does not feel any sufficient support from related departments whenever they are required to use an E-Auction system regularly. Therefore, it does affect their perceived evaluation of the E-Auction system advantages. On the other hand, Sheppard \& Vibert (2019) argued that the insignificance relationship of perceived ease of use and usefulness should be seen as an indication that these model may need to be revised as the rapid change of users' perceptions and behavior and current development practices. Users can still be able to perform the tasks for which a system is built, even if it is difficult to use, but with a system that is simple to use, they would be more effective, efficient, and pleased. Finally, the result of this study support prior finding by Almutairi \& Subramanian (2005), Handayani et al. (2017), Hajiheydari \& Ashkani (2018), Aldosari et al. (2018), Verma et al. (2018), and Kang \& Namkung (2019) that stated there was a positive relationship between system and information quality on perceived usefulness. The value of t-tested between variables as shown in Table 3 was 0.320 and 0.586 with a significant value of 0.003 and 0.000 (which is lower than significances criteria of 0.050 ), therefore $\mathrm{H}_{1}, \mathrm{H}_{3}$ is acceptable. It means that the more positive users' evaluation of the E-Auction system and service quality, the more useful the E-Auction system is perceived.

A second regression analysis was run on system quality and information quality with perceived ease of use as the dependent variable. The model exhibited an adjusted $R^{2}$ of 0.618 (Figure 2). All two variables were significant predictors of perceived ease of use. The value of t-tested between variables as shown in Table 5 was 3.646 and 2.734 with a significant value of 0.008 and 0.000 (which is lower than significances criteria of 0.050 ), therefore $\mathrm{H}_{2}$, $\mathrm{H}_{4}$ is acceptable. This study supports previous studies by Almutairi \& Subramanian (2005), Handayani et al. (2017), Hajiheydari \& Ashkani (2018), Aldosari, Al-Mansour, Aldosari, \& Alanazi (2018), Verma et al. (2018), and Kang \& Namkung (2019) that concluded that there was a positive and significant relationship of system quality, information quality, and perceived ease of use. The more positive users' evaluation of the E-Auction system and service quality, the more ease of use the E-Auction system is perceived.

A third regression analysis was applied on system quality, information quality, service quality with compatibility as the dependent variable. The model exhibited an adjusted $\mathrm{R}^{2}$ of 0.589 (Figure 2). Table 6 of the hypotheses testing shows that this study was only able to confirm $\mathrm{H}_{7 \mathrm{a}}$ and $\mathrm{H}_{7 \mathrm{c}}$, as there were significant effects of system quality and service quality on compatibility $(\beta=0.212,0.214 ; \mathrm{t}=0.035,0.007 ; \mathrm{p}<0.050)$. This study supports prior 
Investigating the success of an E-Auction system initiatives among public servants: Validation of an integrated IS success model by Agus Bandiyono, Abdul Hamid Hudalil Muttaqin

literature by Aldholay et al. (2018) and Sebetci (2018) which concluded that system quality and service quality has a positive effect on compatibility. The higher the quality of system and service offered, the more compatible the interaction of system and users will be. Thus, unlike previous studies by Aldholay et al. (2018) and Sebetci (2018) that found that information quality was a significant predictor of compatibility, the result of this study concluded the opposite. Eppler (2006) stated that there are five issues of compatibility hinder for information quality improvements in e-government initiatives which is an existing resource (such as staff, budget, available time), rules, skills, infrastructure, and reference points (such as official benchmarks or standards of the required attitudes of public servants). Based on open survey questions, the unattractive dashboard, the missing of the "Auction Acta" feature, lack of support and socialization from IS developers, and instability of internet network was mentioned as an issue that respondent faced regularly. It can be concluded that the issue of resources and infrastructure were considered as the most important factors that make the insignificant relationship between information quality and compatibility.

The last regression analysis was applied to all six variables using user satisfaction as the dependent variable. There are 4 of 6 variables were failed to prove the proposed hypotheses. The model exhibited an adjusted $\mathrm{R}^{2}$ of 0.779 (Figure 2). Table 7 shows that information quality and compatibility meaningfully predicts user satisfaction, therefore $\mathrm{H}_{9}, \mathrm{H}_{13}$ is acceptable $(\beta=0.324,0.451 ; \mathrm{t}=3.258,3.408 ; \mathrm{p}<0.050)$. This study supports previous studies by Song et al. (2017), Lien, Cao, \& Zhou (2017), Aldholay et al. (2018), Chen \& Chang (2018), Sebetci, (2018), and Koh \& Kan (2020) that found that information quality and compatibility has a positive effect on user satisfaction. It means that the more compatible, reliable, accurate, understandable, sufficient, and up-to-date information provided by the system, the more satisfied users will be. Meanwhile, system quality, service quality, perceived usefulness, perceived ease of use, and compatibility failed to predicts user satisfaction in this study, therefore it can be concluded that $\mathrm{H}_{8}, \mathrm{H}_{10}, \mathrm{H}_{11}, \mathrm{H}_{12}$ is rejected $(\beta=$ $0.153,-0.008,0.012,0.069 ; \mathrm{t}=1.238,-0.090,0.127,0.650 ; \mathrm{p}>0.050)$. Table 4 shows the comparison of system quality and service quality average score which is described that respondent of this study has not valued the question of "E-Auction system would be user friendly" and "E-Auction system would enable interactive communication" as high as others questions. These same symptoms with a prior study by Mulhanga \& Lima (2017), which is poor interface design and lack of technical support were considered as the primary barriers that deter the successful implementation of IS. Furthermore, Normelindasari \& Solichin (2020), added that whenever user experienced system failure, it would decrease their level of 
satisfaction simultaneously. Lastly, the insignificant effect of perceived usefulness and ease of use on satisfaction may due to the finite alternatives E-Auction system that available for the official member of Directorate Auction, DJKN. Therefore, it makes perceived usefulness and ease of use have not become the key belief that influences their attitude in using the particular IS (Sumaedi et al., 2016). Moreover, the usage of an E-Auction system among the official member of Directorate Auction, DJKN, was considered as mandatory acted that obligated by government and organization policies.

\section{Conclusion and Suggestion}

The purpose of this study was to examine the satisfaction factors of public servants used the E-Auction system that is developed by the Directorate General of State Assets Management (DJKN), Ministry of Finance of Indonesia. This study found that there were only two of six variables that significantly prove as predictors of user satisfaction of EAuction system which is information quality and compatibility. It means that the system designers should pay more attention to designing information quality that compatible with user needs to boost the level of satisfaction. Other constructs such as system quality, service quality, perceived usefulness, and perceived ease of use failed to prove their significant relationship to user satisfaction. Researchers argued that the poor interface design and lack of technical support were the primary concern that is considered as the reason for the insignificant hypotheses result. Moreover, the usage of an E-Auction system that is classified as "order by mandate" makes perceived usefulness and ease of use have not become the key belief that influence their attitude. Interestingly, this study did not find sufficient evidence to support the relationship between perceived ease of use. It seems that users can still be able to perform the tasks for which an E-Auction system is built, even if it is difficult to use, but with a system that is simple to use, they would be more effective, efficient, and pleased. Finally, the issue of resources and infrastructure were considered as the most important factors that make the insignificant relationship between information quality and compatibility in this study. Future studies should extend their theoretical scope and target respondents (the bidder) in a broader way to gain a better perspective. The usage of technology task fit and perceived usefulness with the modification role of perceived ease of use (as a moderator in between) may considered as the extension construct of future study. As in public sectors, IS initiatives were a mandatory approach, then the investigation of the IS success model should focus on the real impact of IS implementation (such as net benefit) rather than user perception. 
Investigating the success of an E-Auction system initiatives among public servants: Validation of an integrated IS success model by Agus Bandiyono, Abdul Hamid Hudalil Muttaqin

\section{References}

Abi Bakri, R. (2013). Sistem lelang online berbasis Web. Electrician, 7(3), 98-107. https://doi.org/https://doi.org/10.23960/elc.v7n3.115

Al-Fraihat, D., Joy, M., Masa'deh, R., \& Sinclair, J. (2020). Evaluating E-learning systems success: An empirical study. Computers in Human Behavior, 102, 67-86. https://doi.org/10.1016/j.chb.2019.08.004

Aldholay, A., Isaac, O., Abdullah, Z., Abdulsalam, R., \& Al-Shibami, A. H. (2018). An extension of Delone and McLean IS success model with self-efficacy. The International Journal of Information and Learning Technology, 35(4), 285-304. https://doi.org/10.1108/IJILT-11-2017-0116

Aldosari, B., Al-Mansour, S., Aldosari, H., \& Alanazi, A. (2018). Assessment of factors influencing nurses acceptance of electronic medical record in a Saudi Arabia hospital. Informatics in Medicine Unlocked, 10, 82-88. https://doi.org/10.1016/j.imu.2017.12.007

Alghazi, S. S., Wong, S. Y., Kamsin, A., Yadegaridehkordi, E., \& Shuib, L. (2020). Towards sustainable mobile learning: A brief review of the factors influencing acceptance of the use of mobile phones as learning tools. Sustainability, 12(24), 10527. https://doi.org/10.3390/su122410527

Almutairi, H., \& Subramanian, G. H. (2005). An empirical application of the DeLone and McLean model in the Kuwaiti private sector. Journal of Computer Information Systems, 43(2), 113-122.

Alzahrani, L., Al-Karaghouli, W., \& Weerakkody, V. (2017). Analysing the critical factors influencing trust in e-government adoption from citizens' perspective: A systematic review and a conceptual framework. International Business Review, 26(1), 164-175. https://doi.org/10.1016/j.ibusrev.2016.06.004

Bandiyono, A., \& Indrianto, N. P. P. (2019). E-Rekon LK application as a form of accounting and information systems implementation in Indonesia. International Journal of Innovation, Creativity and Change, 8(3), 23-40.

Büyüköztürk, Ş., Çakmak, E. K., Akgün, Ö. E., Karadeniz, Ş., \& Demirel, F. (2010). Scientific research methods. Ankara: Pegem Akademi.

Chau, P. Y. K., \& Hu, P. J. (2002). Examining a model of information technology acceptance by individual professionals: An exploratory study. Journal of Management Information Systems, 18(4), 191-229. https://doi.org/10.1080/07421222.2002.11045699

Chen, C.-C., \& Chang, Y.-C. (2018). What drives purchase intention on Airbnb? Perspectives 
of consumer reviews, information quality, and media richness. Telematics and Informatics, 35(5), 1512-1523. https://doi.org/10.1016/j.tele.2018.03.019

Delone, W. H., \& McLean, E. R. (2003). The DeLone and McLean Model of Information Systems Success: A Ten-Year Update. Journal of Management Information Systems, 19(4), 9-30. https://doi.org/10.1080/07421222.2003.11045748

DeLone, W. H., \& McLean, E. R. (1992). Information systems success: The quest for the dependent variable. Information Systems Research, 3(1), 60-95. https://doi.org/10.1287/isre.3.1.60

Eppler, M. J. (2006). A comparison between concept maps, mind maps, conceptual diagrams, and visual metaphors as complementary tools for knowledge construction and sharing. Information Visualization, 5(3), 202-210. https://doi.org/10.1057/palgrave.ivs.9500131

Hajiheydari, N., \& Ashkani, M. (2018). Mobile application user behavior in the developing countries: A survey in Iran. Information Systems, 77, 22-33. https://doi.org/10.1016/j.is.2018.05.004

Handayani, P. W., Hidayanto, A. N., Pinem, A. A., Hapsari, I. C., Sandhyaduhita, P. I., \& Budi, I. (2017). Acceptance model of a Hospital Information System. International Journal of Medical Informatics, $11-28$. https://doi.org/10.1016/j.ijmedinf.2016.12.004

Hung, S.-Y., Ku, Y.-C., \& Chien, J.-C. (2012). Understanding physicians' acceptance of the Medline system for practicing evidence-based medicine: A decomposed TPB model. International Journal of Medical Informatics, 81(2), 130-142. https://doi.org/10.1016/j.ijmedinf.2011.09.009

Ifinedo, P. (2012). Understanding information systems security policy compliance: An integration of the theory of planned behavior and the protection motivation theory. Computers \& Security, 31(1), 83-95. https://doi.org/10.1016/j.cose.2011.10.007

Jafari Navimipour, N., \& Soltani, Z. (2016). The impact of cost, technology acceptance and employees' satisfaction on the effectiveness of the electronic customer relationship management systems. Computers in Human Behavior, 55, 1052-1066. https://doi.org/10.1016/j.chb.2015.10.036

Kang, J.-W., \& Namkung, Y. (2019). The information quality and source credibility matter in customers' evaluation toward food $\mathrm{O} 2 \mathrm{O}$ commerce. International Journal of Hospitality Management, 78, 189-198. https://doi.org/10.1016/j.ijhm.2018.10.011

Kim, T. G., Lee, J. H., \& Law, R. (2008). An empirical examination of the acceptance behaviour of hotel front office systems: An extended technology acceptance model. 
Investigating the success of an E-Auction system initiatives among public servants: Validation of an integrated IS success model by Agus Bandiyono, Abdul Hamid Hudalil Muttaqin

Tourism Management, 29(3), 500-513. https://doi.org/10.1016/j.tourman.2007.05.016

Koh, J. H. L., \& Kan, R. Y. P. (2020). Students' use of learning management systems and desired e-learning experiences: are they ready for next generation digital learning environments? Higher Education Research \& Development, 1-16. https://doi.org/10.1080/07294360.2020.1799949

Landrum, H., \& Prybutok, V. R. (2004). A service quality and success model for the information service industry. European Journal of Operational Research, 156(3), 628642. https://doi.org/10.1016/S0377-2217(03)00125-5

Lee, S.-J., Choi, M. J., Rho, M. J., Kim, D.-J., \& Choi, I. Y. (2018). Factors affecting user acceptance in overuse of smartphones in mobile health services: An empirical study testing a modified integrated model in South Korea. Frontiers in Psychiatry, 9, 658. https://doi.org/10.3389/fpsyt.2018.00658

Liaw, S.-S., \& Huang, H.-M. (2013). Perceived satisfaction, perceived usefulness and interactive learning environments as predictors to self-regulation in e-learning

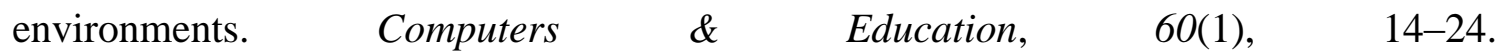
https://doi.org/10.1016/j.compedu.2012.07.015

Lien, C.-H., Cao, Y., \& Zhou, X. (2017). Service quality, satisfaction, stickiness, and usage intentions: An exploratory evaluation in the context of WeChat services. Computers in Human Behavior, 68, 403-410. https://doi.org/10.1016/j.chb.2016.11.061

Lin, H.-C., Chiu, Y.-H., Chen, Y. J., Wuang, Y.-P., Chen, C.-P., Wang, C.-C., ... Ho, W.-H. (2017). Continued use of an interactive computer game-based visual perception learning system in children with developmental delay. International Journal of Medical Informatics, 107, 76-87. https://doi.org/10.1016/j.ijmedinf.2017.09.003

Lin, P., Li, M., Kong, X., Chen, J., Huang, G. Q., \& Wang, M. (2018). Synchronisation for smart factory - towards IoT-enabled mechanisms. International Journal of Computer Integrated Manufacturing, 31(7), 624-635. https://doi.org/10.1080/0951192X.2017.1407445

Lin, W.-S., \& Wang, C.-H. (2012). Antecedences to continued intentions of adopting elearning system in blended learning instruction: A contingency framework based on models of information system success and task-technology fit. Computers \& Education, 58(1), 88-99. https://doi.org/10.1016/j.compedu.2011.07.008

Lowry, P. B., \& Wilson, D. (2016). Creating agile organizations through IT: The influence of internal IT service perceptions on IT service quality and IT agility. The Journal of Strategic Information

Systems, 25(3), $211-226$. 
https://doi.org/10.1016/j.jsis.2016.05.002

Montesdioca, G. P. Z., \& Maçada, A. C. G. (2015). Measuring user satisfaction with information security practices. Computers \& Security, 48, 267-280. https://doi.org/10.1016/j.cose.2014.10.015

Mulhanga, M. M., \& Lima, S. R. (2017). Podcast as e-Learning enabler for developing countries. In Proceedings of the 2017 9th International Conference on Education Technology and Computers - ICETC 2017 (pp. 126-130). New York, New York, USA: ACM Press. https://doi.org/10.1145/3175536.3175581

Mun, Y. P., Khalid, H., \& Nadarajah, D. (2017). Millennials' perception on mobile payment services in Malaysia. Procedia Computer Science, 124, 397-404. https://doi.org/10.1016/j.procs.2017.12.170

Namin, A. (2017). Revisiting customers' perception of service quality in fast food restaurants. Journal of Retailing and Consumer Services, 34, 70-81. https://doi.org/10.1016/j.jretconser.2016.09.008

Normelindasari, D., \& Solichin, A. (2020). Effect of system quality, information quality, and perceived usefulness on user satisfaction of webstudent applications to improve service quality for Budi Luhur University Students. In Proceedings of the 4th International Conference on Management, Economics and Business (ICMEB 2019). Paris, France: Atlantis Press. https://doi.org/10.2991/aebmr.k.200205.016

Nwankpa, J., \& Roumani, Y. (2014). Understanding the link between organizational learning capability and ERP system usage: An empirical examination. Computers in Human Behavior, 33, 224-234. https://doi.org/10.1016/j.chb.2014.01.030

Pinem, A. A., Yeskafauzan, A., Handayani, P. W., Azzahro, F., Hidayanto, A. N., \& Ayuningtyas, D. (2020). Designing a health referral mobile application for high-mobility end users in Indonesia. Heliyon, 6(1), e03174. https://doi.org/10.1016/j.heliyon.2020.e03174

Rahman, M. M., Deb, S., Carruth, D., \& Strawderman, L. (2020). Using technology acceptance model to explain driver acceptance of advanced driver assistance systems (pp. 44-56). https://doi.org/10.1007/978-3-030-20503-4_5

Rana, N. P., Dwivedi, Y. K., Williams, M. D., \& Weerakkody, V. (2015). Investigating success of an e-government initiative: Validation of an integrated IS success model. Information Systems Frontiers, 17(1), 127-142. https://doi.org/10.1007/s10796-0149504-7

Rauschnabel, P. A., \& Ro, Y. K. (2016). Augmented reality smart glasses: an investigation of 
Investigating the success of an E-Auction system initiatives among public servants: Validation of an integrated IS success model by Agus Bandiyono, Abdul Hamid Hudalil Muttaqin

technology acceptance drivers. International Journal of Technology Marketing, 11(2), 123. https://doi.org/10.1504/IJTMKT.2016.075690

Saha, P., Nath, A. K., \& Salehi-Sangari, E. (2012). Evaluation of government e-tax websites: an information quality and system quality approach. Transforming Government: People, Process and Policy, 6(3), 300-321. https://doi.org/10.1108/17506161211251281

Samsurijal, H. (2019). The influence of service quality, distribution performance and customer orientation to customer satisfaction and its impact on corporate image (Study on water supply company Tirta Siak in Riau Province). Jour of Adv Research in Dynamical \& Control Systems, Vol. 11(Special Issue-08), 1258-1270.

Santoso, D. S., \& Bourpanus, N. (2019). Moving to e-bidding. Journal of Financial Management of Property and Construction, 24(1), 2-18. https://doi.org/10.1108/JFMPC-05-2018-0025

Sasongko, T. (2018). The role of employee motivation on the relationship between HRM practices and service quality in healthcare organization. JEMA: Jurnal Ilmiah Bidang Akuntansi Dan Manajemen, 15(01), 1. https://doi.org/10.31106/jema.v15i01.782

Sebetci, Ö. (2018). Enhancing end-user satisfaction through technology compatibility: An assessment on health information system. Health Policy and Technology, 7(3), 265-274. https://doi.org/10.1016/j.hlpt.2018.06.001

Seddon, P. B. (1997). A Respecification and Extension of the DeLone and McLean Model of IS Success. Information Systems Research, 8(3), 240-253. https://doi.org/10.1287/isre.8.3.240

Sheppard, M., \& Vibert, C. (2019). Re-examining the relationship between ease of use and usefulness for the net generation. Education and Information Technologies, 24(5), 3205-3218. https://doi.org/10.1007/s10639-019-09916-0

Song, J., Migliaccio, G. C., Wang, G., \& Lu, H. (2017). Exploring the influence of system quality, information quality, and external service on bim user satisfaction. Journal of Management in Engineering, 04017036. https://doi.org/10.1061/(ASCE)ME.1943-5479.0000549

Sumaedi, S., Bakti, I. G. M. Y., Rakhmawati, T., Astrini, N. J., Widianti, T., \& Yarmen, M. (2016). Factors influencing public transport passengers' satisfaction: a new model. Management of Environmental Quality: An International Journal, 27(5), 585-597. https://doi.org/10.1108/MEQ-05-2015-0084

Sun, P.-C., Tsai, R. J., Finger, G., Chen, Y.-Y., \& Yeh, D. (2008). What drives a successful e-Learning? An empirical investigation of the critical factors influencing learner 
satisfaction. Computers \& Education, 50(4), 1183-1202. https://doi.org/10.1016/j.compedu.2006.11.007

Sun, S., Lee, P. C., Law, R., \& Zhong, L. (2020). The impact of cultural values on the acceptance of hotel technology adoption from the perspective of hotel employees. Journal of Hospitality and Tourism Management, 44, 61-69. https://doi.org/10.1016/j.jhtm.2020.04.012

Svidronova, M. M., \& Mikus, T. (2015). E-procurement as the ICT innovation in the public services management: case of Slovakia. Journal of Public Procurement, 15(3), 317-340.

Verma, S., Bhattacharyya, S. S., \& Kumar, S. (2018). An extension of the technology acceptance model in the big data analytics system implementation environment. Information Processing \& Management, 54(5), 791-806. https://doi.org/10.1016/j.ipm.2018.01.004

Wang, Y.-S. (2008). Assessing e-commerce systems success: a respecification and validation of the DeLone and McLean model of IS success. Information Systems Journal, 18(5), 529-557. https://doi.org/10.1111/j.1365-2575.2007.00268.x

Zaied, A. N. H. (2012). An integrated success model for evaluating information system in public sectors. Journal of Emerging Trends in Computing and Information Sciences, $3(6), 814-825$.

Zhang, R., Li, G., \& Sun, Z. (2014). Relationship between consumer innovativeness and internet banking acceptance. In 2014 International Conference on Management Science \& Engineering 21th Annual Conference Proceedings (pp. 308-314). IEEE. https://doi.org/10.1109/ICMSE.2014.6930245 